\title{
Unemployment and speed of adjustment in ASEAN-3 economies: a cointegration analysis
}

\begin{abstract}
This paper investigates the existence of long-run relationship between unemployment and several key macroeconomic variables in Malaysia, Singapore, and the Philippines. The Johansen-Juselius cointegration method confirms the existence of a stationary long-run cointegration relationship between unemployment and its determinants in all three countries. Exports and foreign direct investment are important determinants of unemployment in Malaysia. In the Philippines, government spending and exports are inversely related to unemployment. In Singapore, only exports appeared as a significant factor in determining unemployment. The results show that the speed of adjustment following a shock is more rapid in Singapore compared to the other two ASEAN countries.
\end{abstract}

Keyword: Unemployment; Speed of adjustment; Malaysia; Singapore; The Philippines 